\title{
Numerical Simulation of Building Foundation Stability above Old Longwall Goaf
}

\author{
Ning Jiang \\ State Key Laboratory of Mine Disaster \\ Prevention and Control \\ Shandong University of Science and \\ Technology \\ Qingdao, China \\ jiangning198961@163.com \\ Xikun Chang \\ State Key Laboratory of Mine Disaster \\ Prevention and Control \\ Shandong University of Science and \\ Technology \\ Qingdao, China \\ changxikun@sina.com
}

\author{
Shaojie Chen \\ State Key Laboratory of Mine Disaster \\ Prevention and Control \\ Shandong University of Science and \\ Technology \\ Qingdao, China, Corresponding author, \\ chensj@sdust.edu.cn \\ Weijia Guo \\ State Key Laboratory of Mine Disaster \\ Prevention and Control \\ Shandong University of Science and \\ Technology \\ Qingdao, China \\ wjguo@sdust.edu.cn
}

\author{
Dawei Yin \\ State Key Laboratory of Mine Disaster \\ Prevention and Control \\ Shandong University of Science and \\ Technology \\ Qingdao, China, \\ 949251142@qq.com
}

\begin{abstract}
In orderto analyze and evaluate the residual deformation of longwall goaf and its effect on new buildings, the stability of building foundation above the old longwall goaf was studied using the FLAC ${ }^{3 D}$ software. According to the results of probability integral method, the mechanical parameters of the geologic body were solved by inversion analysis. The subsidence deformation of building foundation above longwall goaf under the ground building loads and vertical stress were calculated by numerical simulation. By comparing the deformation of building foundation above longwall goaf before and after grouting and building, the stability of building foundation above longwall goaf and the security of the building were evaluated.
\end{abstract}

Keywords-old longwall goaf, foundation, stability evaluation, residual deformation, numerical simulation

\section{INTRODUCTION}

There are more than 150 coal mine cities in China. A large number of coal mine subsidence have formed in China, after long-term and large-scale mining of coal resources. There are more than 2 million hectares of coal mine subsidence in total, and mainly distributed in densely populated and economically developed central and eastern region of China [1-3]. With the rapid development of economy, society and infrastructure construction in China, construction land is increasingly strained. Construction using of coal mine subsidence is an effective measure to solve the construction land bottleneck of coal mine city.

Goaf as a kind of bad geological body, the stability of goaf must be evaluated before building a building above it. Subsidence area foundation stability appraisal is a prerequisite for construction using of coal mine subsidence, which has attracted the attention of domestic and foreign scholars. Guo et al analysis the time course of surface movement and discusses the prediction method of surface movement duration and surface residual deformation [4]. Teng and Zhang suggested the analysis of foundation stability and determination of building floors (height) according to the non-overlapping influence depth of building load and development height of fracture zone in the goaf [5]. Tan et al studied the stability of the building foundation and deformational and destructive law through the methods of combining field investigation with theoretical analysis $[6,7]$. Some scholars studied the influence of dynamic load on the stability of goaf [8-10]. Some scholars also suggested that the evaluation of foundation stability above goaf using the fuzzy mathematics comprehensive evaluation [11, 12]. Field investigation has the disadvantages of long time and large investment. It is difficult to consider various factors and to obtain intuitive results using the theoretical analysis. Finite element simulation can obtain intuitive results quickly with full condition of a variety of factors. With the rapid development of computer technology, finite element simulation is used to analyze the deformation of the foundation and the building above the goaf $[13,14]$. This paper compared and analyzed the deformation values of foundation before and after grouting by the method of finite element simulation, it provides a reference for evaluating the stability of building foundation and the safety of building.

\section{GEOLOGICAL AND MINING CONDITIONS}

Shandong Lanhai Linghang E-commerce Industrial Park Project is a Provincial Key Project in Shandong Province of China in 2014, which is invested by Shandong E-commerce Integrated Operations Management Co. Ltd. The total investment of the project is 4.3 billion yuan, covers an area of $92.73 \mathrm{ha}$, and the planned total building area is 1.1 million square meters, which will create a well-known e-commerce base in the province. In the first phase of construction, Shandong Lanhai Linghang the core area of the e-commerce industry park (A district), covering an area of 10 ha. The first priority is building No. 1\# building of the data processing center, with a floor height of $24.0 \mathrm{~m}$ (1st floor underground, 4 floors above ground), $84.84 \mathrm{~m}$ in length, and $59.64 \mathrm{~m}$ in width from north to south. This article uses the data 
processing center No. 1\# building as the engineering background. study the building foundation stability above old longwall goaf.

According to the survey, there are No. 4\# coal, No. 9\# coal, and No. 10-2\# coal old goaf distributed in the building site of $1 \#$ building of the data processing center. Mining status of coal seams are shown in Table 1. No. 10-2\# coal is eroded by magmatic rocks, and the coal seam is extremely unstable and locally recoverable. There is a sporadic distribution of No. 10-2\# coal goaf in this area, which is ignored in this paper.

The overlying strata in the studied area mainly include Quaternary topsoil, medium sandstone, shale, mudstone, limestone, and fine sandstone. The thickness of the Quaternary top soil layer is approximately $10.0 \mathrm{~m}$, and the lithology of the entire overburden rock belongs to medium hard.

TABLE I. MINING STATUS OF COAL SEAMS

\begin{tabular}{|c|c|c|c|c|c|c|c|}
\hline Coal seam & Mining time & $\begin{array}{c}\text { Buried depth } \\
/ \mathbf{m}\end{array}$ & $\begin{array}{l}\text { Average mining thick } \\
/ \mathrm{m}\end{array}$ & $\begin{array}{c}\text { Recovery rate } \\
1 \%\end{array}$ & $\begin{array}{l}\text { Coal mining } \\
\text { method }\end{array}$ & $\begin{array}{c}\text { Coal mining } \\
\text { process }\end{array}$ & $\begin{array}{l}\text { Roof management } \\
\text { method }\end{array}$ \\
\hline $\begin{array}{c}\text { No. 4\# } \\
\text { coal }\end{array}$ & Before 1972 & $27 \sim 33$ & 0.67 & 50 & $\begin{array}{l}\text { Roadway } \\
\text { mining }\end{array}$ & \multirow{3}{*}{$\begin{array}{l}\text { Blasting } \\
\text { mining }\end{array}$} & \multirow{3}{*}{$\begin{array}{l}\text { Bulk caving } \\
\text { method }\end{array}$} \\
\hline $\begin{array}{c}\text { No.9\# } \\
\text { coal }\end{array}$ & 2012 & $115 \sim 123$ & 1.09 & 85 & $\begin{array}{l}\text { Along strike } \\
\text { longwall }\end{array}$ & & \\
\hline $\begin{array}{l}\text { No. 10-2\# } \\
\text { coal }\end{array}$ & 2002 & $133 \sim 137$ & 1.18 & 70 & $\begin{array}{l}\text { Roadway } \\
\text { mining }\end{array}$ & & \\
\hline
\end{tabular}

\section{RESIDUAL SUBSIDENCE VALUE OF OLD GOAF}

Because No. 4\# coal used roadway mining, buried depth shallow, lack of date, after the experts of the constructor's organization argued: It's possible suddenly caving after grounting treatment in No. 4\# coal goaf, and $4 \#$ coal buried depth shallow, to ensure the safe operation of the 1\# building of the data processing center in the later period, recommended "Pile+Raft" foundation, pile end bearing layer is $4 \#$ coal.

According to the measured results of residual settlement in the working face, it is found that the residual settlement is still basically in line with the basic characteristics of mining subsidence basins. Therefore, the residual settlement of the old goaf is expected to still use the probability integral method. When the probability integral method predicts the residual deformation of old goaf, parameter changes are mainly subsidence coefficient, other parameters may be taken as the value at the time of full exploitation. Because the pile crosses the No. 4\# coal goaf, therefore, the goaf that threatens the safety of buildings in the studied area is only No. 9\# coal goaf.

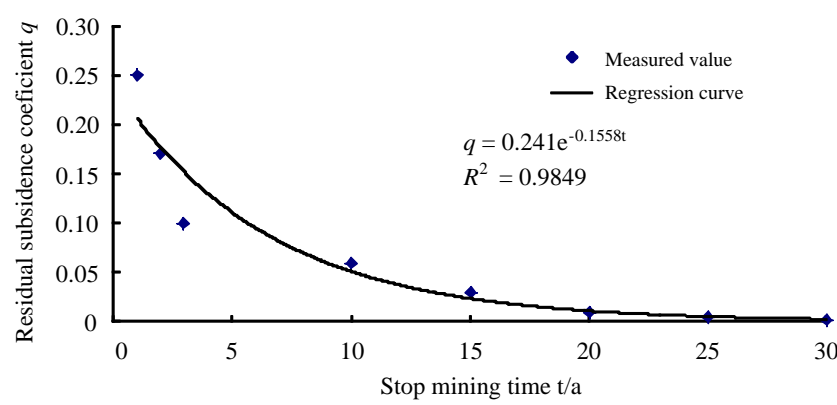

Fig.1 Relationship between residual subsidence coefficient and stopping mining time

There are two main reasons that cause surface residual settlement in old goafs: slow creep deformation and "activation" instability. No. 9\# coal goaf is longwall goaf, the main cause of residual settlement on the surface is slow creep deformation. The residual sedimentation coefficient dominated by slow creep deformation can be selected with reference to Fig. 1. Using the fitting equation, the maximum residual settlement coefficient of the No. 9\# coal goaf (stop mining $3 a$ ) in the study area was calculated to be 0.151 , the maximum residual subsidence of the No. 9\# coal goaf in the study area is $164.6 \mathrm{~mm}$. The above calculation results are only the surface residual settlement of the old goaf, and do not include the settlement of the foundation itself and the compression of the pile body under the action of the building load. When estimating the settlement of buildings above the old goaf, the pile compression under the upper load should be calculated and the settlement of the foundation under the load of buildings should be calculated according to the conventional soil mechanics method. The evaluation of the settlement of foundations above the old goaf is the sum of the foundation settlement value under the action of the building load, the surface residual settlement value of the old goaf and the compression of the pile body, if the No. 9\# coal gob area is not treated, the settlement value may exceed the building deformation requirements[15], therefore, in order to ensure the operational safety of the No. 1\# building of the data processing center, it was decided to carry out grouting reinforcement treatment for the No. 9\# coal goaf.

\section{ESTABLISHMENT OF THREE DIMENSIONAL CALCULATION MODEL}

In the exploration area of the study area, there are several layers of strata with different thickness and different properties. In order to simplify the calculation, the rock layers in the study area are divided into loose petrofabric (Quaternary), sandstone petrofabric, mudstone petrofabric, limestone petrofabric, and fractured petrofabric (Goaf accumulation rock mass) according to the lithology and integrity. A total of 5 types of petrofabric, from top to bottom, it was divided into 22 petrofabric. The 3D geological body model is shown in Fig. 2.

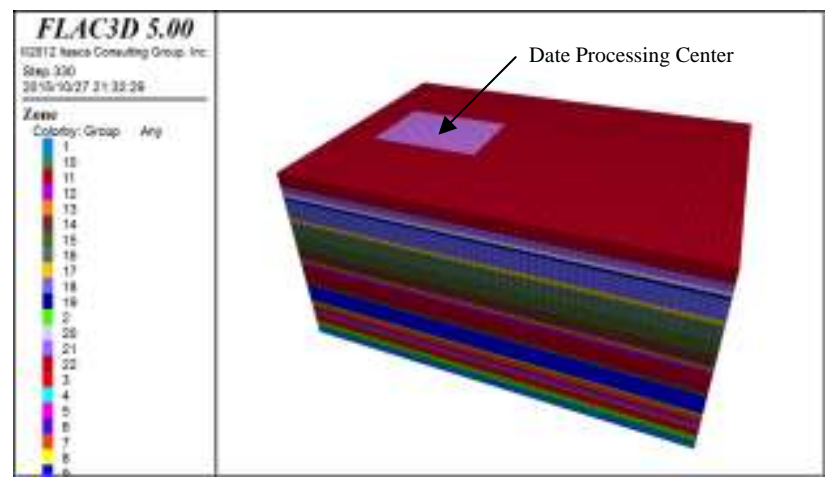

Fig.2 3D geometrical model of the geologic body 
In the division of petrofabric, the No. 9\# coal goaf (caving zone and fractured zone) were divided into fractured rock petrofabric, according to the "Building, Water, Railway and Lane Pillar and Pressure Coal Mining Regulations," the calculated thickness is $20.4 \mathrm{~m}$. The model size is length $\times$ width $\times$ height $=340 \mathrm{~m} \times 200 \mathrm{~m} \times 137.7 \mathrm{~m}$, a total of 159000 units, 167994 nodes.

\section{GEOLOGICAL BODY MECHANICS PARAMETERS}

The mechanical parameters commonly used in numerical calculations are the mechanical properties of rock masses obtained through laboratory tests. However, due to the anisotropy of the rock mass, the in-situ rock mechanical properties cannot be characterized by the mechanical test results of the rock block. In the geotechnical engineering numerical calculation, the mechanical parameters are generally taken from the empirical values given by the engineering analogy method, or the indoor test values are reduced, or obtained through the inversion fitting method. The geophysical parameters in this article are obtained by inversion.

The specific ideas and steps are:

(1) Using the probability integration method to estimate the amount of residual settlement in old goafs.

(2) Comprehensive evaluation of indoor rock block mechanics test, in-situ test and similar engineering experience, and assignment of mechanical parameters of various petrofabrics.

(3) Trial calculations and adjustments are repeated until the calculated results are in good agreement with the predicted values of residual settlement of old goafs. It can

Tab.2 Stratum physical and mechanical parameters of the geologic model

\begin{tabular}{|c|c|c|c|c|c|c|c|c|c|}
\hline \multirow[t]{2}{*}{ Petrofabric } & \multirow{2}{*}{$\begin{array}{l}\text { Bulk modulus } \\
\text { (GPa) }\end{array}$} & \multirow{2}{*}{$\begin{array}{c}\text { Shear } \\
\text { modulus } \\
(\mathrm{GPa})\end{array}$} & \multicolumn{2}{|c|}{ Cohesion(MPa) } & \multicolumn{2}{|c|}{$\begin{array}{c}\text { Internal friction } \\
\text { angle } \\
\left({ }^{\circ}\right)\end{array}$} & \multicolumn{2}{|c|}{$\begin{array}{c}\text { Tensile } \\
\text { strength(MPa) }\end{array}$} & \multirow{2}{*}{$\begin{array}{l}\text { Density } \\
\left(\mathrm{kg} / \mathrm{m}^{3}\right)\end{array}$} \\
\hline & & & $\begin{array}{c}\text { Test } \\
\text { value }\end{array}$ & $\begin{array}{l}\text { Fitted } \\
\text { value }\end{array}$ & $\begin{array}{c}\text { Test } \\
\text { value }\end{array}$ & $\begin{array}{l}\text { Fitted } \\
\text { value }\end{array}$ & $\begin{array}{c}\text { Test } \\
\text { value }\end{array}$ & $\begin{array}{l}\text { Fitted } \\
\text { value }\end{array}$ & \\
\hline Loose petrofabric & 0.08 & 0.009 & - & 0.036 & - & 20 & - & 0.001 & 1800 \\
\hline Mudstone petrofabric & 2.45 & 1.76 & $3 \sim 12$ & 1.00 & $35 \sim 36$ & 25 & $2.5 \sim 4.5$ & 0.78 & 2500 \\
\hline $\begin{array}{l}\text { Limestone } \\
\text { petrofabric }\end{array}$ & 13.4 & 6.15 & $>10$ & 6.00 & 39 & 32 & $7 \sim 12$ & 6.00 & 2800 \\
\hline Sandstone petrofabric & 17.80 & 9.85 & $5 \sim 15$ & 5.00 & $31 \sim 40$ & 30 & $5 \sim 10$ & 5.00 & 2760 \\
\hline $\begin{array}{l}\text { Fractured petrofabric } \\
\text { (Unprocessed) }\end{array}$ & 0.25 & 0.03 & - & 0.042 & - & 18 & - & 0.002 & 1800 \\
\hline $\begin{array}{c}\text { Fractured } \\
\text { petrofabric(Grouting) }\end{array}$ & 2.0 & 1.43 & - & 1.20 & - & 20 & - & 0.002 & 2050 \\
\hline
\end{tabular}

be considered that the material parameters are basically in line with reality.

The specific process is shown in Fig. 3.

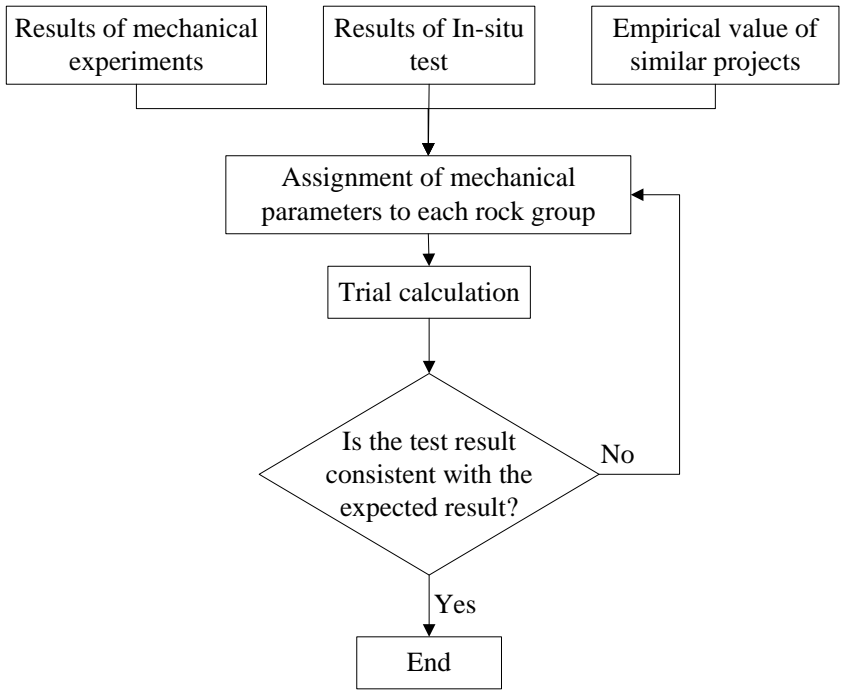

Fig.3 Flow chart of inversion fitting of mechanical parameters of geologic body

After the simulation calculation, the maximum residual subsidence of the model is $143.85 \mathrm{~mm}$, it is basically consistent with the expected maximum residual subsidence of $164.6 \mathrm{~mm}$ estimated by the probability integration method, therefore, it can be considered that the fitting result is more realistic. The values listed in Table 2 are the actual mechanical parameters of the petrofabric in the study area.

\section{A. Results}

The physical and mechanical parameter values of each petrofabric obtained by inversion fitting, on this basis, the mechanical parameters of the loose petrofabric in the goaf are "strengthening". indicates that grouting reinforcement is performed in the goaf. The "strengthened" treatment loose petrofabric parameters are entered into the program for calculation. using the Mohr-Coulomb criterion, after the grouting reinforcement, the foundation settlement deformation results in the study area, as shown in Fig. 4. The base unit is set according to the designed base depth and appropriate mechanical parameters are given. The input mechanical parameters are calculated again using the 


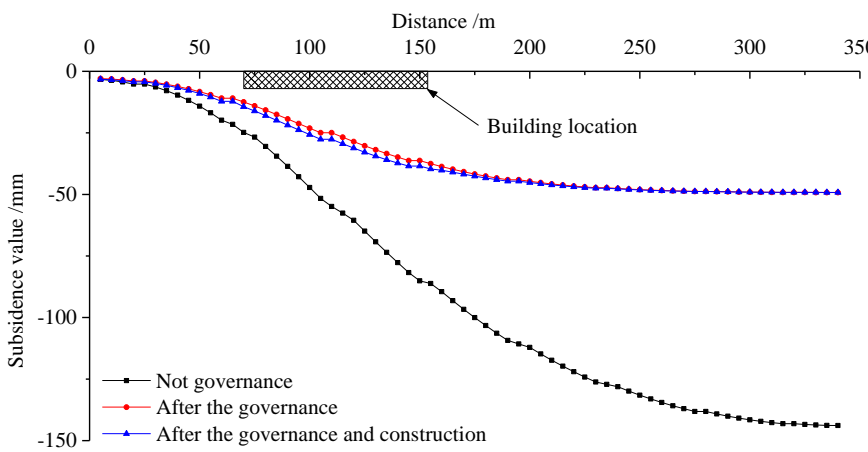

Fig.4 Subsidence deformation of the foundation

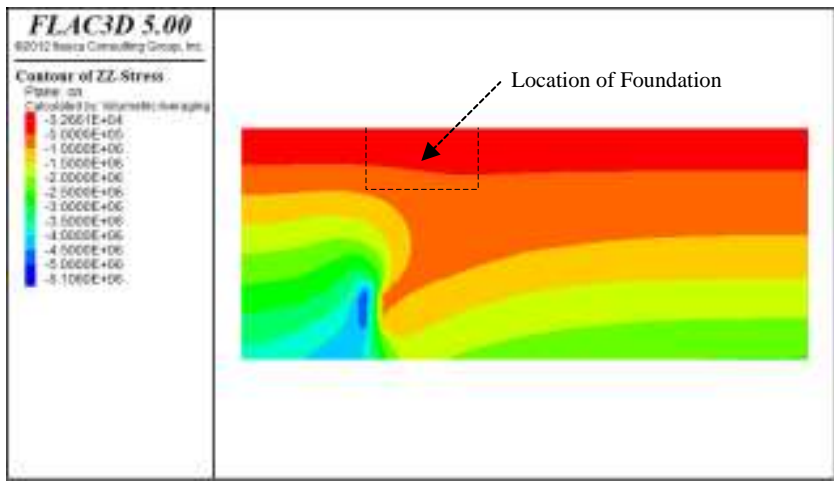

(a) Before grouting and building

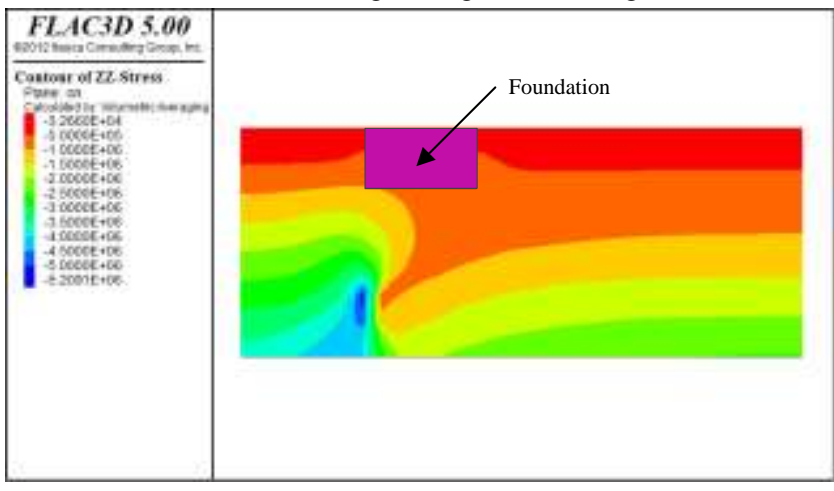

(b) After grouting and building

Fig.5 Vertical stress of the foundation as the goaf reinforced and before and building

\section{B. Analysis of results}

Comparative analysis Fig. 4:

(1) After grouting the broken rock mass in the No. 9\# coal goaf, the maximum residual settlement on the surface varied from $143.85 \mathrm{~mm}$ to $49.22 \mathrm{~mm}$ And the residual settlement of the surface is reduced by $65.78 \%$ with obvious effect.

(2) Under the effect of ground building loads, the maximum residual settlement at the surface of the building increased to $41.66 \mathrm{~mm}$, which was $4.17 \mathrm{~mm}$ higher than that before the building was not built.

(3) The effect of building load on the surface residual deformation decreases with increasing distance from the building.

Comparative analysis Fig. 5: Under the action of the upper building load, the vertical stress distribution in the foundation above the goaf is more uniform and the value is not large.

After a comparative analysis, after the grouting reinforcement of the goaf, the residual settlement of the foundation is small, and the stress distribution of the base is uniform, the range of additional stress caused by building loads is small. The ground building load will not affect the No. 9\# coal goaf. In the same way, the presence of No. 9\# coal goaf will not affect the safety of the surface buildings. This area is suitable for the construction of 1\# building of data processing center after grouting reinforcement.

\section{CONCLUSION}

(1) The residual settlement of longwall old goaf can be calculated using the probabilistic integral method as the criterion for the FLAC3D simulation. Therefore, the most realistic geological mechanics parameters were inverted and fitted in FLAC ${ }^{3 \mathrm{D}}$ software.

(2) Numerical simulations revealed changes in foundation settlement before and after grouting in the longwall goaf and before and after construction, and distribution of vertical stress in the foundation. After the simulation calculation, after the grouting reinforcement in the goaf, the maximum residual settlement value at the building is only $37.47 \mathrm{~mm}$, after adding the upper building load, the maximum residual settlement value increased to $41.66 \mathrm{~mm}$, the amount of deformation meets the building deformation requirements, therefore, the goaf area is processed to meet the construction requirements of the No. $1 \#$ building of the data processing center.

\section{ACKNOWLEDGEMENTS}

This study was supported by the National key research and development plan (2018YFC0604700), the National Natural Science Foundation of China (51474134, 51774194), Shandong Provincial Natural Science Fundation for Distinguished Young Scholars (JQ201612), Major basic research projects of Shandong Natural Science Foundation (ZR2018ZC0740), Natural Science Foundation of Shandong Province (no.ZR2016EEB23), Science and Technology Program of Shandong Provience University (no.J15LH02), Taishan Scholar Talent Team Support Plan for Advantaged \& Unique Discipline Areas and Graduate student science and technology innovation project of Shandong University of Science and Technology (SDKDYC180201).

\section{REFERENCES}

[1] G. L. GUO, Deformation mechanism and control of building foundation above old goafs. Xuzhou: China University of Mining and Technology press, 2001.

[2] Y. B. ZHANG, Research on the stability of building foundation above old mine goafs and its damage regula. Taiyuan: Taiyuan university of technology, 2005.

[3] K. Z. DENG, Z. X. TAN, and H. Z. ZHANG, "Design method of strip grouting for old longwall mining goaf," J. China Coal Soc., vol. 32, pp. 153-156, 2008.

[4] W. J. GUO, and Y. Y. WANG, "Stability evaluation of constructing large-scale building-toft above mine goaf,". Rock and Soil Mechanics, 2004, 25(S1): 57-59.

[5] Y. H. TENG, and J. Y. ZHANG, "Evaluation on stability of building foundation over goafs," J. China Coal Soc., vol. 22, pp. 504-508, 1997.

[6] Z. X. TAN, and K. Z. DENG, "Study on change laws of additional ground reaction force of buildings in mining area," J. China Coal Soc., vol. 32, pp. 907-911, 2007. 
[7] P. XU, W. B. GUO, and M. X. ZHANG, "Methods of controlling movement and deformation of mining induced bridge," J. Min Safety Eng, vol. 28, pp. 425-429, 2011.

[8] Q. B. GUO, "Research on the safety evaluation and key technologies foe the expressway construction on old goaf of coal mine," Xuzhou: China university of mining and technology, 2017.

[9] G. DUAN, "Analysis of the stability of mined-out areas under train load," Qingdao: Qing university of technology, 2013.

[10] T. J. CUI, Y. D. MA, and L. G. WANG, "Simulation and research on surface subsidence caused by abandoned goaf under earthquake," J. Syst Simul, vol. 28, pp. 634-639, 2016.

[11] R. G. Yan, "Mining-induced foundation subsidence and foundation construction," Beijing: Metallurgical Industry Press, 1995.

[12] Beijing Mining Institute, "Surface movement and overburden failure law in coal mines as well as its applications," Beijing: China Coal Industry Publishing Home, 1982.

[13] J. L. WANG, C. J. DING, Y. ZHANG, and S. L. WU, "Numerical analysis of effect of abandoned goaf foundation deformation on ground buildings," J. Min Safety Eng, vol. 25, pp. 476-480, 2008.

[14] Z. F. SUN, "The research of numerical simulation for the depth mining's effect on stability of the building foundation with old goaf," Taiyuan: Taiyuan university of technology, 2005.

[15] Ministry of Housing and Urban-Rural Development of the People's Republic of China. Code for design of building foundation[S]. Beijing: China Architecture and Building Press, 2011. 